Vol. 6, No. 1, 2021

\title{
CONFUSING PROBLEM OF GREEN ARCHITECTURE AND FALSE GREEN ARCHITECTURE IN MENA REGION
}

\author{
Nima Norouzi ${ }^{1}$, Zahra Nasiri $^{2}$ \\ ${ }^{I}$ Department of energy engineering and physics, \\ Amirkabir university of technology (Tehran polytechnic), \\ 424, Hafez Ave., PO Box 15875-4413, Iran, \\ ${ }^{2}$ Department of engineering, \\ Islamic Azad university (Ardabil Branch), \\ Ardabil, Iran \\ nima1376@aut.ac.ir_zn65133@gmail.com
}

https://doi.org/10.23939/ep2021.01.048

Received: 01.02.2021

(C) Norouzi N., Nasiri Z., 2021

\begin{abstract}
Achieving sustainable and environmentally friendly architecture is one of the main goals people have made to better life as the final model for their professional activities. Thus, moving towards greener architecture is considered the primary goal of the architecture of our time. The purpose of this study is to analyze architectural projects that have already been implemented in Middle Eastern countries in terms of their compatibility with the objective concepts of sustainability and the green standards they require. Therefore, for review and study, the purpose of this article is to discover the level of sustainability classification system such as LEED (Leadership in Energy and Environmental Design) that can be effective in classifying current architectural projects. Studies show three concepts for analyzing contemporary architecture: 1. green, 2. false green, and 3. energy-seller. Besides, these studies have shown that some projects, although attempting to convey sustainable architecture concepts in appearance, are not sustainable. In recent stages, this paper intends to evaluate the effectiveness of the LEED classification system. In evaluating the LEED classification system, the results show that the system's purpose is more for planning purposes than objective design goals and practical tools for analyzing the architectural design process. The analysis based on this study shows that it is necessary to use design-based patterns to move false green architecture to green architecture.
\end{abstract}

Key words: sustainable built environment, green architecture, green building, green standards.

\section{Introduction}

Green building (also known as green building or sustainable building) refers to structures and utilization processes that are environmentally responsible and resource-effective in the building life cycle: from design to construction, operation, maintenance, repair, and demolition. This requires the close collaboration of the design team, architects, structural engineers, and the client at all stages of the project (Cryer et al., 2006). In general, green buildings use energy, water, and materials to make resources more efficient throughout the building's life, including the initial construction phase (Elmualim et al., 2012). Green buildings use techniques, materials, and methods to reduce the negative impact of the building on the environment while increasing the comfort, health, and utility of its residents (Reed et al., 2009). The term green building can refer to a sustainable building or high performance; These terms are often used interchangeably, although there are differences. More recently, the philosophy of green and sustainable construction has been incorporated into what can be described as a movement based on "creating a healthy built environment according to ecological principles," while at the same time considering the "whole life cycle of the built environment" (Sussman, 2008). Although

For citation: Norouzi N., Nasiri Z., 2021. Confusing problem of green architecture and false green architecture in MENA region. Journal Environmental Problems. Vol. 6, No. 1. p. 48-58. DOI: https://doi.org/10.23939/ep2021.01.048 
new technologies are continually evolving to complement new functions in the construction of greener structures, the common goal is that green homes are designed to reduce the overall impact of the built environment on human health and the natural environment ( Murga et al., 2020).

These days, there are several global standards and classification systems for determining the degree of greenness in green buildings. LEED (Leadership in Energy and Environmental Design) is the most popular sustainable classification system used in the United States (Elmualim et al., 2012; Sussman, 2008). The Green Gobbs system is also famous for smaller projects because it provides an online guide with a third-party verification process. Another less commonly used criterion in the United States is the BREEAM Structural Research (BREEAM) (Kong et al., 2020). Some cities, such as Seattle, and many countries, such as Canada, Australia, and Japan, have their standards. These systems are similar to the US LEED classification and BREEAM, which have a guaranteed point system for classifying various stable components and a mechanism for securing the building (Hu et al., 2020). For this article, developing countries' approach to green buildings has been selected, so the study of ten green buildings in the Middle East is considered, and the amount of greenery of these buildings is measured. To achieve this, we have compiled a list of 8 components of green architecture, and in each component, the amount of green, false green, and energyseller is recorded. On the other hand, the LEED estimation system is selected as the standard system set globally, and based on these standard components, the degree of greenness is calculated. The evaluation obtained from the lists is then compared to the LEED norms' conclusion, and the relationship between them is calculated.

\section{Methodology}

\subsection{Theoretical framework}

Climatic situations in the Middle East, especially in the entire desert areas around the Gulf, where the temperature difference between day and night, require high energy consumption to make habitats livable and increased fossil fuels use. They are mainly involved in air pollution and rising temperatures, forcing nations to solve this significant problem. Fortunately, the sudden surge in oil revenues has made it possible to find the best solution to move towards green building, which has seen significant growth in combating harsh environmental conditions. But this article determines that most of these buildings can be in the category of false green rather than green buildings. To understand the greenness of buildings, we have listed a list of 8 components related to green buildings in the table. This list is called "Designer" and is based on design criteria (Al-Habaibeh et al., 2020; Chen et al., 2020).

On the other hand, at the end of the case study evaluation, a list of LEED norms is provided, a green classification for each building. This list is called "planning." This study shows three concepts in the analysis of contemporary architecture that are as follows: 1) green, 2) false green, and 3) energy-seller. The categories of green, false green, and energy-seller are evaluated in the designer's list for all eight components.

"Green" means something completely natural. For example, whenever natural plants are used as living organisms, whether on the roof, walls, or structure of a building, or under natural ventilation and natural light, these buildings are considered green. "False green" indicates something that is artificially green and not entirely natural. For example, when the wall structure is made of timber cut from trees or for ventilation purposes, the appearance of a windbreak is used in the building; these components can be called false green. "Energyseller" refers to something that is not green and consumes energy. For example, the ventilation and lighting system is used without natural forces and more energy consumption. These components can be considered energy-seller.

\subsection{Methods and Materials}

The designer list includes eight components: ceiling, wall, structure, materials, ventilation, lighting, heating/cooling, and water management. These eight components are prepared for each of the ten buildings in a separate table. Besides identifying the amount of green, false green, and energy-vendor for each component, this data was collected from each building's websites or those buildings' architects. This data is recorded in a list table with a Likert scale. The proposed Likert scale format has five components, which include the following:

1. Lack of concept

2. Low concept rate

3. Mean value of the concept

4. A relatively large amount of concept

5. Complete concept categorization

On the other hand, these data are recorded in the planning list based on the Likert scale derived from the LEED sustainable classification system's twenty-five components. 
This data is entered into the "Microsoft Excel Database" and analyzed to determine how green each building is. Finally, separate diagrams are obtained for designer and planning lists. These diagrams are compared in SPSS 19 Static Software, and the common factors between them are calculated.

\section{Casestudy}

These days in the Middle East, we see a significant increase in green building technology. This part of the world is growing more in the economic age, so considerable construction industry progress. The challenge of moving towards green architecture has become a significant competition in different countries. Approximately 1,300 LEED-certified commercial building projects can be seen in the urban landscape of Middle Eastern countries. A new survey of architects, structural engineers, and construction jobs shows that $73 \%$ of project respondents have a new green enterprise projected in the UAE (Li et al., 2020). In this study, ten different buildings in Middle Eastern countries that are successful green projects have been evaluated. Efforts have been made to select buildings measured by the LEED classification system as green buildings or buildings that LEED will evaluate in the future (Chen et al., 2020).

\subsection{Abu Dhabi Alder Bazaar}

Foster and his partners are behind the landscaping of Abu Dhabi Central Shock (Fig. 1). By adding a series of small increases in the ecology of permeable shops, hotels, offices, and restaurants such as roof gardens, the world-renowned company has steadily promoted this old global market (Al-Habaibeh et al., 2020).

The Central Bazaar is one of the oldest sections in Abu Dhabi. Foster \& partners Co. wanted to build a store complex that did not expose the store's commercial vulgarity. Instead, Alder Central Market is a new signlike grid that includes intimate balconies, alleys, and courtyards, highlighted by three iconic towers. The complex of overgrown gardens makes for a relaxing public park in a secluded desert town. Aldar Central Market is a city within the city (Amiri Fard, Nasiri, F., 2020). Unlike commercial property, visitors are meant to use public spaces while they need a park - to relax, study, enjoy the sun, socialize - not just a place to relax. Legs are tired of shopping. The building, which occupies two urban blocks, has sliding walls and ceilings that reduce energy costs by further developing natural ventilation and lighting. Alder Central Market is a creative architectural project added to Abu Dhabi's captivating skyline - with the pleasant addition of public park space. Table 1 shows the classification of green building components based on the designer list on the Abu Dhabi Alder Bazaar.

Table 1

\section{Classification of Green Building Components} in Abu Dhabi Alder Bazaar

\begin{tabular}{|c|c|c|c|}
\hline Components & Green & $\begin{array}{c}\text { False } \\
\text { green }\end{array}$ & $\begin{array}{c}\text { Energy- } \\
\text { seller }\end{array}$ \\
\hline ceiling & 4 & 2 & 1 \\
\hline Wall & 1 & 5 & 1 \\
\hline Structure & 1 & 3 & 3 \\
\hline Materials & 1 & 4 & 2 \\
\hline Ventilation & 4 & 1 & 2 \\
\hline Lighting & 3 & 1 & 3 \\
\hline Heating and cooling & 1 & 2 & 4 \\
\hline Water management & 4 & 2 & 1 \\
\hline
\end{tabular}

\subsection{Abu Dhabi Parliament Building}

This majestic parliament building with a magnificent lattice dome in Abu Dhabi designed by the Ehrlich Architecture Group can be considered an excellent example of an energy-efficient green building. By combining passive solar design and unique desert architecture techniques, the company ensured that the highly efficient parliament building did not use much energy (Amiri Fard, Nasiri, F., 2020). Table 2 shows the classification of building components based on the list of designers in the $\mathrm{Abu}$ Dhabi Parliament building.

Table 2

\section{Classification of green building components in Abu Dhabi parliament building}

\begin{tabular}{|c|c|c|c|}
\hline Components & Green & $\begin{array}{c}\text { False } \\
\text { green }\end{array}$ & $\begin{array}{c}\text { Energy- } \\
\text { seller }\end{array}$ \\
\hline ceiling & 1 & 2 & 4 \\
\hline Wall & 1 & 2 & 4 \\
\hline Structure & 1 & 2 & 4 \\
\hline Materials & 1 & 3 & 3 \\
\hline Ventilation & 4 & 2 & 2 \\
\hline Lighting & 4 & 1 & 5 \\
\hline Heating and cooling & 1 & 1 & 1 \\
\hline Water management & 4 & 2 & \\
\hline
\end{tabular}




\subsection{Kuwait International Airport}

Lou and Foster and their partners are still behind another green project in the Middle East. This time they have unveiled plans to build a high-powered international airport in Kuwait. Although the country does not have its green building standard, it has developed this strangely shaped project to LEED gold standards (Cryer et al., 2006).

Foster and partners recently announced that they would design a new Kuwait International Airport - and plan to make it the first LEED-certified passenger terminal! Undoubtedly, the ground and sky's excellent design attracts attention and raises the airport's environmental level wherever it is with a set of green components, which will reduce the building's energy consumption and cool it in one of the hottest parts of the earth. Table 3 shows the classification of greenhouse components based on the design list at Kuwait International Airport.

Table 3

\section{Classification of green building components in Kuwait International Airport}

\begin{tabular}{|c|c|c|c|}
\hline Components & Green & $\begin{array}{c}\text { False } \\
\text { green }\end{array}$ & $\begin{array}{c}\text { Energy- } \\
\text { seller }\end{array}$ \\
\hline ceiling & 1 & 1 & 5 \\
\hline Wall & 1 & 1 & 5 \\
\hline Structure & 1 & 2 & 4 \\
\hline Materials & 1 & 3 & 3 \\
\hline Ventilation & 3 & 3 & 1 \\
\hline Lighting & 4 & 1 & 2 \\
\hline Heating and cooling & 2 & 2 & 3 \\
\hline Water management & 5 & 1 & 1 \\
\hline
\end{tabular}

\subsection{Madar Zero Carbon City}

The city of Masdar is one of the most notable projects in the Middle East. As the world's first zerocarbon and zero-emission city, it has attracted attention, but economic problems surround it. Sustainable buildings in the color of Foster clay and partners are eye-catching.

The city of Masdar gives Abu Dhabi a life without carbon Foster and partners. Family work is complemented by fluff, clowns, and princesses, which, in addition to giving visitors a first-hand look at some of the world's most advanced architectures and onesize-fits-all developments, have been impressive examining the city's first eco-market and organic market. It also creates eco-businesses and organizations, such as the Land Art Generator Initiative, an opportunity to promote their good green works - which is understandable at first glance. Table 4 shows the classification of green building components based on the list of designers in Masdar, Abu Dhabi.

Table 4

\section{Classification of green building components in Masdar City}

\begin{tabular}{|c|c|c|c|}
\hline Components & Green & $\begin{array}{c}\text { False } \\
\text { green }\end{array}$ & $\begin{array}{c}\text { Energy- } \\
\text { seller }\end{array}$ \\
\hline ceiling & 1 & 3 & 3 \\
\hline Wall & 1 & 1 & 5 \\
\hline Structure & 1 & 2 & 4 \\
\hline Materials & 1 & 3 & 3 \\
\hline Ventilation & 3 & 1 & 3 \\
\hline Lighting & 3 & 2 & 2 \\
\hline Heating and cooling & 4 & 2 & 1 \\
\hline Water management & 4 & 2 & 1 \\
\hline
\end{tabular}

\subsection{Bank with radiant dome Morocco}

Morocco is technically in Africa, but most people think it is a mysterious country in the Middle East. This project was the first project of Foster \& Partners in that country and perhaps one of their most beautiful projects. This dramatic domed bank features several ancient Arabic design techniques and a unique heating system that keeps it cool in summer.

Table 5

Classification of green building components in BMCE

\begin{tabular}{|c|c|c|c|}
\hline Components & Green & $\begin{array}{c}\text { False } \\
\text { green }\end{array}$ & $\begin{array}{c}\text { Energy- } \\
\text { seller }\end{array}$ \\
\hline ceiling & 1 & 2 & 4 \\
\hline Wall & 3 & 3 & 1 \\
\hline Structure & 1 & 2 & 4 \\
\hline Materials & 1 & 3 & 3 \\
\hline Ventilation & 4 & 1 & 2 \\
\hline Lighting & 4 & 1 & 3 \\
\hline Heating and cooling & 3 & 1 & 1 \\
\hline Water management & 4 & 2 & 2 \\
\hline
\end{tabular}

Foster \& Partners Co. has built sustainability projects worldwide, but the world-renowned company has never completed an Africa project before. The first two of the three projects commissioned by BMCE (Bank 
of Morocco) were built in Rabat and Casablanca and have many sustainable features: energy efficiency, ecofriendly materials, etc. free-cooling system. Take a closer look at this beautiful building, which is based on traditional Arabic design.

The modern entrance (illuminated by light) is surrounded by adequate external energy modeled according to the traditional geometric design. To keep the heat down, the lattice plates were made of low-iron stainless steel, almost tangled. This maintains high energy efficiency, so the building requires minimal cooling. In addition to indigenous crafts during construction, indigenous materials such as black granite and gray limestone played a significant role in the design. Due to the allegory in modern Turkish architecture, the dome was placed on all three BMCE buildings. The interior was furnished with Tadlaque, a native plaster technique, while the exterior is adorned with gallows, which are traditional ceramic tiles. Notice how the dome at the bottom enters the bank hall to create a magnificent, functional bench.

Eventually, Foster and his partners installed a freestanding cooling system called the "ground duct". The system uses fresh air to enter the empty pipe surrounding the building's basement, which naturally cools the ground and flows in various branches. Table 5 shows the classification of green building components based on the bank's designer list with the Moroccan radiant dome.

\subsection{Sustainable Bamboo Dome in Iran}

Made of fast-growing bamboo and complete with dry spikes of rice (straw), this organic dome near Katalam, Iran, was designed by Pouya Khazaeli Parsa. Inspired by one of his students trying to build a dome replica at the university, this real shelter was used as a model for developing a shelter in the area. Bio-economic, economical, and made from native natural materials, this sustainable shelter can also be built at any time.

With three people's help, the shelter can be built in two days, made of seventy bamboo straws. The selfpropelled shelter base was made of gas pipes from a local store to ensure that the structure could be relocated if necessary. The fast-growing renewable plant remains for up to two days after being cut to be flexible and soft. The bamboo dome structure was completed with dry clusters of rice available in the area and are biofertilizer and waterproofing. When it rains, the plants scatter, and the shelter stays dry. When it is sunny and warm, the north wind blows in them for cooling and natural ventilation. Because of their shape, these domes can be utterly resistant to wind or earthquake, making them quite economical in emergency housing (Table 6).
Table 6

Classification of green building components in Sustainable Bamboo Dome

\begin{tabular}{|c|c|c|c|}
\hline Components & Green & $\begin{array}{c}\text { False } \\
\text { green }\end{array}$ & $\begin{array}{c}\text { Energy- } \\
\text { seller }\end{array}$ \\
\hline ceiling & 1 & 5 & 1 \\
\hline Wall & 1 & 5 & 1 \\
\hline Structure & 1 & 5 & 1 \\
\hline Materials & 1 & 5 & 1 \\
\hline Ventilation & 5 & 1 & 1 \\
\hline Lighting & 5 & 1 & 1 \\
\hline Heating and cooling & 5 & 1 & 1 \\
\hline Water management & 1 & 5 & 1 \\
\hline
\end{tabular}

\subsection{Al-Wakrah World Cup Stadium, Qatar}

Qatar's controversial 2022 World Cup plan received a star when the famous Iraqi architect Zaha Hadid, one of Time Magazine's 100 most influential figures in 2010, was selected to join AECOM to design Al-Wakrah Stadium. The 45,000-seat modular stadium will feature Islamic architectural elements to match Qatar's residential area, south of Doha. The design, which includes the city's cultural heritage, will serve as an urban oasis complemented by a water center, mineral water, and commercial space.

Believe it or not, the countries that have already entered the auction to host the 2022 World Cup and Qatar have submitted a bid, which includes a large capacity of solar-powered stadiums and significant facilities for their public transport network. If they win the auction, Qatar will build three completely new green stadiums and upgrade existing ones to host the games. Table 7 shows the classification of green building components based on the designer list at the Al Wakrah World Cup Stadium in Qatar.

Table 7

Classification of green building components in Al-Wakrah World Cup Stadium

\begin{tabular}{|c|c|c|c|}
\hline Components & Green & $\begin{array}{c}\text { False } \\
\text { green }\end{array}$ & $\begin{array}{c}\text { Energy- } \\
\text { seller }\end{array}$ \\
\hline ceiling & 1 & 1 & 5 \\
\hline Wall & 1 & 1 & 5 \\
\hline Structure & 1 & 1 & 5 \\
\hline Materials & 1 & 3 & 3 \\
\hline Ventilation & 5 & 1 & 1 \\
\hline Lighting & 4 & 1 & 1 \\
\hline Heating and cooling & 5 & 1 & 1 \\
\hline Water management & 4 & 2 & \\
\hline
\end{tabular}




\subsection{Casablanca Grand Stadium in Morocco}

Escao from France collaborated on the Moroccan arch's design to give the national football team a wholly new and stable stadium. Concrete structures such as fish feathers develop natural ventilation and a passive design that keeps the building beautiful and cool.

The large Casablanca stadium was built in an old mine with a passive solar design with concrete blades such as fish feathers that allow for natural ventilation. The 100-hectare site was formerly a mine, and plans for a new stadium were abandoned and empty. Inspired by the mine site itself, the large Casablanca stadium was designed to look like a mineral. The open-air stadium is surrounded by large perforated concrete walls, which act as a canopy and provide natural ventilation. Among the covering of the blades and the stadium's interior is the garden, which acts as a thermal barrier and an oasis for the spectators. Natural daylight enters through lattice-like blades, which are carefully oriented to allow the desired amount of sunlight to enter. The blades go up to provide shadows for the spectators, creating a large hole for daylight and playground. Table 8 shows the classification of green building components based on the Grand Casablanca Stadium design list in Morocco.

Table 8

Classification of green building components in Casablanca Grand Stadium in Morocco

\begin{tabular}{|c|c|c|c|}
\hline Components & Green & $\begin{array}{c}\text { False } \\
\text { green }\end{array}$ & $\begin{array}{c}\text { Energy- } \\
\text { seller }\end{array}$ \\
\hline ceiling & 1 & 2 & 4 \\
\hline Wall & 1 & 2 & 4 \\
\hline Structure & 1 & 1 & 5 \\
\hline Materials & 1 & 2 & 4 \\
\hline Ventilation & 5 & 1 & 1 \\
\hline Lighting & 4 & 1 & 2 \\
\hline Heating and cooling & 4 & 1 & 2 \\
\hline Water management & 4 & 1 & 2 \\
\hline
\end{tabular}

\subsection{Dubai Sustainable City}

Diamond contractors selected Baharesh Architecture Group to designate the second phase of Dubai Sustainable City - a 46-hectare town, 500 ecodevelopment villas for construction at Al-Quadra and Emirates's junction Roads in Dubai. "The city vision includes three main pillars of sustainability: environmental, economic, and social," Diamond contractors last stated. They added that the proposal is the best performance in environmental construction technologies, while their cost is reasonable.

Phase two of the project will include a multifunctional building for 100 villas and a townhouse with energy efficiency and solar power. The area includes the Grand Mosque, the Institute for Ecological Engineering, the Museum and Skyscraper, the Green School for K-6, the Eco Shelter, the Country Club, and the Equestrian Center.

Each residence is equipped with solar panels expected to generate at least $60 \%$ of their energy needs, and intelligent water systems reduce water consumption by up to $30 \%$. Upon completion, Dubai Sustainable City will have 550 solar-powered villas, solar-powered transportation to prevent gas emissions in the area, organic farms, and a high-level waste management system. Besides, all gray and black waters are collected and recycled for irrigation purposes. Diamond contractors strive to ensure that $50 \%$ of the city will include green spaces with better shade and nitrogen soil quality. Table 9 shows the classification of green building components based on the designer list in Dubai's sustainable city.

Table 9

\section{Classification of green building components in Dubai Sustainable City}

\begin{tabular}{|c|c|c|c|}
\hline Components & Green & $\begin{array}{c}\text { False } \\
\text { green }\end{array}$ & $\begin{array}{c}\text { Energy- } \\
\text { seller }\end{array}$ \\
\hline ceiling & 4 & 2 & 1 \\
\hline Wall & 2 & 2 & 3 \\
\hline Structure & 1 & 2 & 4 \\
\hline Materials & 1 & 2 & 4 \\
\hline Ventilation & 4 & 1 & 2 \\
\hline Lighting & 4 & 1 & 4 \\
\hline Heating and cooling & 2 & 1 & 3 \\
\hline Water management & 3 & 1 & \\
\hline
\end{tabular}

\subsection{Dubai Pearl}

Dubai Pearl is designed for the area near Dubai's new shopping malls, and according to contractors, the program will help with energy efficiency, "smart technology", free-column design, and a walkable environment that makes community life possible. According to the Dubai Pearl Publishing Office, the 40acre (16-hectare) site will include one million square feet of open space and street space, with 15.500 parking spaces, 1.500 residential units, 1.400 offices, and retail outlets that will gradually support 30.000 people. 
So how will development be sustainable? Dubai Pearl contractors have designed an extensive plan to ensure that the energy efficiency they expect will meet the integrated LEED gold certification. Recycling facilities for paper, glass, and food will be part of the complex's significant operation support. The components of intelligent lighting and water retention will also minimize the impact of Dubai Pearl on the native environment. Table 10 shows the classification of building components based on the Designer List in Dubai Pearl.

Table 10

\section{Classification of green building components} in Dubai Pearl

\begin{tabular}{|c|c|c|c|}
\hline Components & Green & $\begin{array}{c}\text { False } \\
\text { green }\end{array}$ & $\begin{array}{c}\text { Energy- } \\
\text { seller }\end{array}$ \\
\hline ceiling & 4 & 2 & 1 \\
\hline Wall & 1 & 2 & 4 \\
\hline Structure & 1 & 1 & 5 \\
\hline Materials & 1 & 2 & 4 \\
\hline Ventilation & 4 & 1 & 2 \\
\hline Lighting & 3 & 1 & 3 \\
\hline Heating and cooling & 2 & 1 & 4 \\
\hline Water management & 3 & 3 & 1 \\
\hline
\end{tabular}

\section{Discussion}

\subsection{Design-based analysis}

According to the summary of the designer lists results, we can evaluate each case study's green classification based on the design process. Table 11 shows the green, false green, and energy-seller categories for ten green buildings in the Middle East based on designer lists.

Fig. 1 shows the data results, the amount of green, false green, and energy-seller for each of the ten green buildings in the Middle East. We can see that the stable bamboo dome building has the highest green factor of $45 \%$. Also, this building has more of a false green factor, i.e., $55 \%$. The Dubai Pearl Building has the highest energy-seller factor of $52 \%$. Therefore, according to Fig. 1, we can conclude that greenness classification according to the design criteria in these buildings is between $30 \%$ and $45 \%$.

Table 11

Classify ten green buildings in the Middle East based on the designer list

\begin{tabular}{|c|c|c|c|}
\hline Building & Green & $\begin{array}{c}\text { False } \\
\text { green }\end{array}$ & $\begin{array}{c}\text { Energy- } \\
\text { seller }\end{array}$ \\
\hline $\begin{array}{c}\text { Abu Dhabi Aldar } \\
\text { Bazaar }\end{array}$ & 2 & 3 & 2 \\
\hline $\begin{array}{c}\text { Abu Dhabi Parliament } \\
\text { Building }\end{array}$ & 2 & 2 & 3 \\
\hline $\begin{array}{c}\text { Kuwait International } \\
\text { Airport }\end{array}$ & 2 & 2 & 3 \\
\hline City of Masdar & 3 & 2 & 3 \\
\hline Radiant dome bank & 3 & 2 & 3 \\
\hline Al Wakrah Stadium & 3 & 1 & 1 \\
\hline Stable bamboo \\
structure & 2 & 4 & 3 \\
\hline Casa Blanca Stadium & 3 & 2 & 3 \\
\hline Dubai Sustainable City & 3 & 2 & 2 \\
\hline Dubai Pearl & 3 & & 3 \\
\hline
\end{tabular}

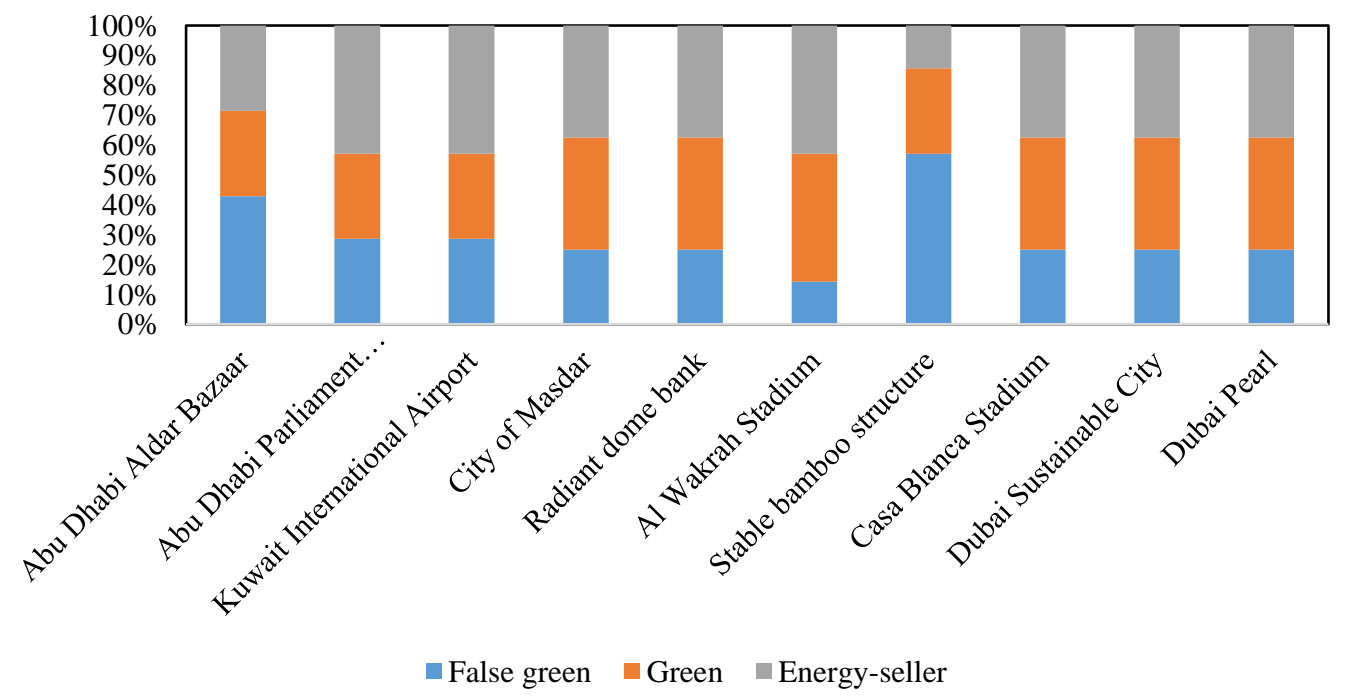

Fig. 1. The amount of green, false green, and energy-seller in ten green buildings in the Middle East according to the designer list 


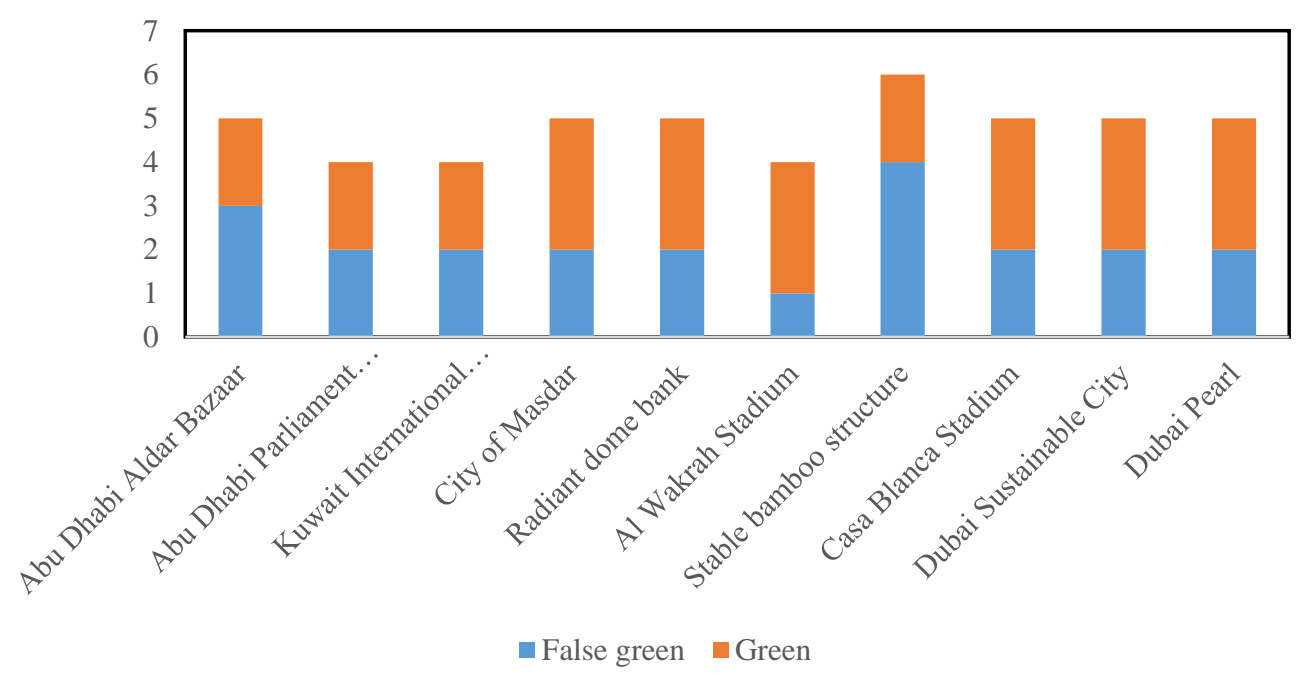

Fig. 2. The amount of green in ten green buildings in the Middle East according to the LEED rating system translation: The names of ten buildings

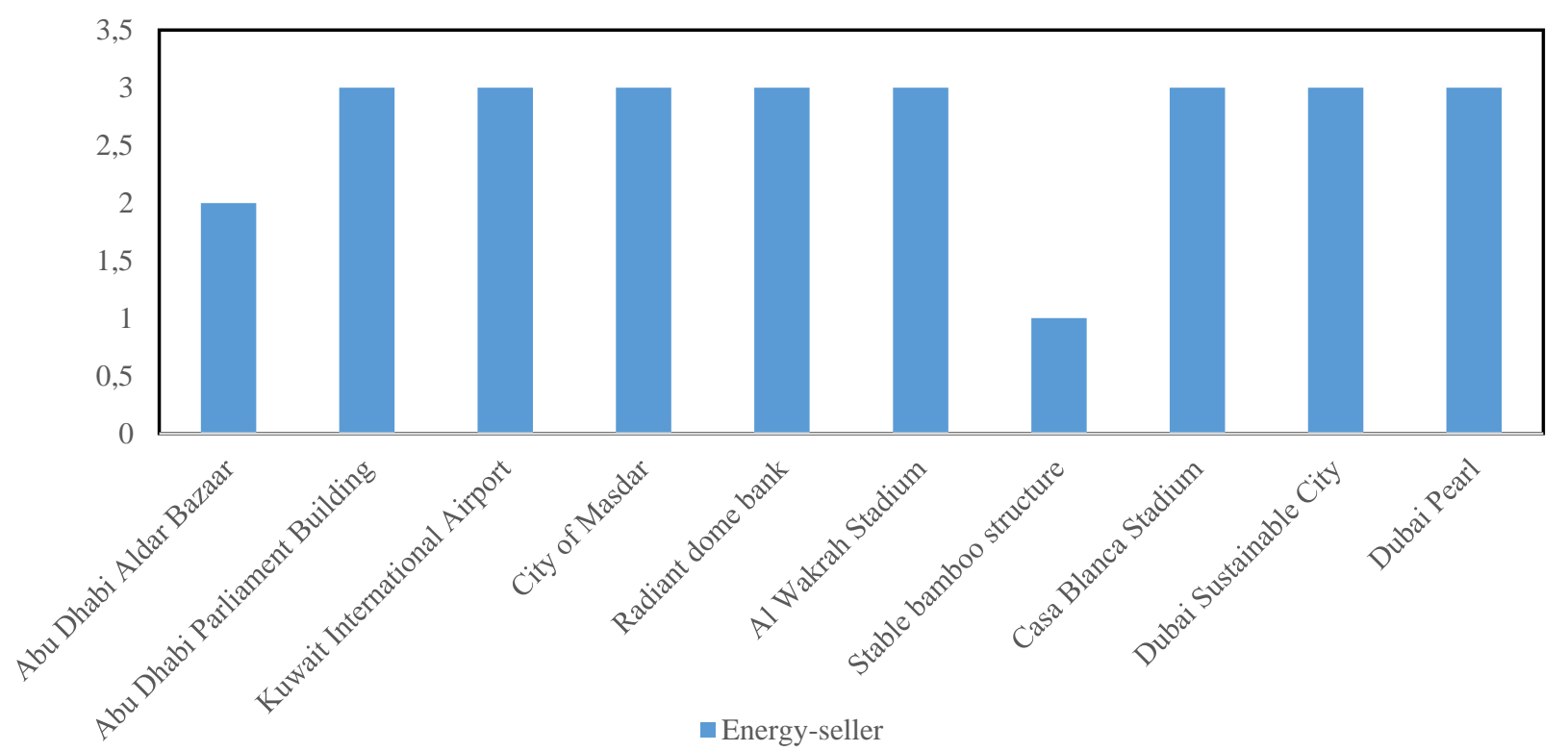

Fig. 3. Comparison between the results of designer and planning directories

\subsection{Planning-oriented analysis}

Leadership in Energy and Environmental Design (LEED) is a voluntary green building classification system. LEED-certified buildings have complemented strategies to reduce building operating costs, environmental rejection, and resource consumption, such as water and energy use. LEED projects are designed, built, and implemented to prevent $\mathrm{CO}_{2}$ emissions while also supporting strategies to build a healthier indoor environmental quality (Yadegaridehkordi et al., 2020; Porumb et al., 2020; Dong et al., 2020). As new technologies emerge, policy changes, and the built-in environment evolves, LEED will respond through refinement-based agreement through an ongoing process.
LEED has six main categories: sustainable sites, water efficiency, energy and atmosphere, materials and resources, internal environmental quality, and operational innovation with four possible certification levels (certification, silver, gold, and platinum). Each of the six credit categories in LEED includes four different LEED strategies used and are related to credits and prerequisites (Wang, Zheng, 2020; Zhilei et al., 2020; He, Chen, 2020; Feng et al., 2020). In this paper, the LEED classification system is selected as the universally recognized standard, and according to the components of this standard, the green classification is evaluated. Therefore, the planning analysis of this paper is based on the components of the LEED classification system. Based on the data collected from case studies, we have recorded the greenness 
classification for each LEED strategy in the planning list. Tables 1 to 11 show the green classification for ten green buildings in the Middle East based on planning list data. The data were recorded using the Likert scale.

Fig. 2 from the planning list data shows the amount of green for each of the ten green buildings in the Middle East. We can see that Al-Durr Bazaar's buildings in Abu Dhabi and the city of Masdar have the highest green factor of $71 \%$. Besides, the stable bamboo dome has the lowest green factor of $24 \%$. Also, from Fig. 2, we can conclude that the classification of green in these buildings according to LEED planning is between $24 \%$ and $71 \%$, and the average between them is about $50 \%$.

\subsection{Deductive analysis}

According to the findings of design-oriented and planning-oriented analyzes, we can compare them. Figure 3 shows the analogy between the results of the designer and planning data. From this analogy, it can be seen that the results of the design and planning data are not consistent, and there is only one adaptation in the "Dubai Sustainable City Complex." The results are very different for the Abu Dhabi and Al-Masdar tool building. The green classification in the Abu Dhabi Bazaar Alder building is $30 \%$ based on design analysis, while this value for the building is $70 \%$ based on planning analysis (Agyekum, et al., 2020). This mismatch between the two variables indicates that the LEED classification system focuses more on planning than design. Besides, the system recognizes false green and green as similar concepts and in many cases, both of which are taken into account in its evaluation; While in design criteria, these components are not considered in the same way. Therefore, we consider only those components that are entirely green and natural (Chi et al., 2020; Wu et al., 2020; Norouzi, Kalantari, 2020; Fan et al., 2018a; Fan et al., 2018b).

Tables 12 and 13 show descriptive statistics for designer and planning data. The average data is $37.1 \%$ for the design variable and $50.1 \%$ for the planning variable. This average classification indicates being green based on LEED classification system strategies higher (Norouzi et al., 2021). Therefore, it seems that the LEED classification system evaluates some factors that are dependent on planning, and these factors can not have a good impact on the building design process. The standard deviation is $5.2 \%$ for the designer variable and $14.1 \%$ for the planning variable. The results of the planningbased analysis are more diverse than the results of the design-based analysis.

Descriptive figures for designer and planning data

\begin{tabular}{|c|c|c|c|}
\hline Variables & Mean & Std.Dev. & Number \\
\hline designer & 37.05 & 5.244 & 10 \\
\hline planning & 50.01 & 14.066 & 10 \\
\hline
\end{tabular}

Table 13

- Common factor of coherence between design and planning components

\begin{tabular}{|c|c|c|c|c|}
\hline Variable & & & Designer & Planing \\
\hline \multirow[t]{6}{*}{$\begin{array}{l}\text { Rho- } \\
\text { Spireman }\end{array}$} & \multirow[t]{3}{*}{ Designer } & $\begin{array}{l}\text { The } \\
\text { common } \\
\text { factor of } \\
\text { cohesion }\end{array}$ & 1.0000 & -3.720 \\
\hline & & $\begin{array}{l}\text { Sig. (2- } \\
\text { tailed) }\end{array}$ & & 0.2840 \\
\hline & & Number & 10.000 & 10.000 \\
\hline & \multirow[t]{3}{*}{ planing } & $\begin{array}{l}\text { A } \\
\text { common } \\
\text { factor of } \\
\text { cohesion }\end{array}$ & -3.720 & 1.0000 \\
\hline & & $\begin{array}{l}\text { Sig. (2- } \\
\text { tailed) }\end{array}$ & 0.2840 & \\
\hline & & Number & 10.000 & 10.000 \\
\hline
\end{tabular}

According to the figures obtained from the analysis of designer and planning variables, we can calculate their relationship. Figures 1 to 3 show the relationship between design variables and Spearman programming. The typical factor relationship between them is -0.374 . It can be seen that there is no relationship between the list-based design variable and the planning variable based on LEED plans and strategies (Norouzi, Soori, 2020). This typical factor relationship also indicates that there are several unknown variables in this evaluation.

\section{Conclusion}

Sustainability is increasingly becoming a key consideration in construction jobs, policymakers, and similar industries, as the world moves toward green construction. When buildings are green, the effect of energy and greenhouse gas emissions is significant. Green buildings can be built with different materials and construction methods that create different traces of accumulated carbon. Green crops can have low energy consumption and can also be beneficial to the environment and nature. Therefore, the use of green materials as the most critical renewable materials in all aspects of human existence appears to be the most effective way to optimize resource use and reduce the 
environmental impact associated with social activities. Progress towards real green architecture, which means the efficient use of all living natural elements and energies in nature, is essential in contemporary architecture. The concept of green is false, but many mistakenly believe that the two are similar.

Thus, although they try to have the appearance of sustainable architectural concepts, some projects are not sustainable and green enough. Besides, in some cases, the LEED classification system shows green and false green in the same sense. The right orientation that is necessary to move forward is green; Hence, moving towards greener architecture is considered the primary goal of contemporary architecture. Based on the information obtained from the analysis of the results, it can be concluded that the LEED classification system takes into account many components that may not have a good effect on the architectural design process of green buildings. This tool is not a design-oriented classification system, but many of its components indicate several new components in analyzing the degree of stability in building construction.

\section{Acknowledgment}

"no fundings were used for this paper".

\section{References}

Agyekum, K., Kissi, E., \& Danku, J. C. (2020). Professionals' views of vernacular building materials and techniques for green building delivery in Ghana. Scientific African, 8, 00424, doi: https://doi.org/10.1016/j.sciaf.2020.e00424

Al-Habaibeh, A., Sen, A., \& Chilton, J. (2020). Evaluation Tool For The Thermal Performance of Retrofitted Buildings Using An Integrated Approach of Deep Learning Artificial Neural Networks and Infrared Thermography. Energy and Built Environment. doi: https://doi.org/10.1016/ j.enbenv.2020.06.004

Amiri Fard, F., \& Nasiri, F. (2020). A bi-objective optimization approach for selection of passive energy alternatives in retrofit projects under cost uncertainty. Energy and Built Environment, (1), 77-86. doi: https://doi.org/10.1016/ j.enbenv.2019.11.005

Chen, G., Rong, L., Zhang, G. (2020). Numerical simulations on atmospheric stability conditions and urban airflow at five climate zones in China. Energy and Built Environment, (2020). doi: https://doi.org/10.1016/j.enbenv.2020.07.006

Chi, B., Lu, W., Ye, M., Bao, Z., \& Zhang, X. (2020). Construction waste minimization in green building: A comparative analysis of LEED-NC 2009 certified projects in the US and China. Journal of Cleaner Production, (256), 120749. doi: https://doi.org/10.1016/j.jclepro.2020.120749.
Cryer, B., Felder, J., Matthews, R., Pettigrew, M., \& Okrent, B. (2006). Evaluating the Diffusion of Green Building Projects. Retrieved from http://personal.anderson.ucla.edu/ charles.corbett/papers/diffusion_green_building.pdf

Elmualim, A., Valle, R., \& Kwawu, W. (2012). Discerning policy and drivers for sustainable facilities management practice. Int. J. Sust. Built Environ. 1, 16-25.

Fan, K., Chan, E.H.W., \& Chau, C.K. (2018a). Costs and Benefits of Implementing Green Building Economic Incentives: Case Study of a Gross Floor Area Concession Scheme in Hong Kong. Sustainability, 10, 2814.

Fan, K., Chan, E.H.W., \& Qian, Q.K. (2018b). Transaction costs (TCs) in green building (GB) incentive schemes: Gross Floor Area (GFA) Concession Scheme in Hong Kong. Energy Policy, (119), 563-573. https://doi.org/10.1016/ j.enpol.2018.04.054

Feng, Q., Chen, H., Shi, X., \& Wei, J. (2020). Stakeholder games in the evolution and development of green buildings in China: Government-led perspective. Journal of Cleaner Production, (275), 122895. doi: https://doi.org/10.1016/ j.jclepro.2020.122895

Fu, Y., Dong, N., Ge, Q., Xiong, F., \& Gong, C. (2020). Driving-paths of green buildings industry (GBI) from stakeholders' green behavior based on the network analysis. Journal of Cleaner Production, (273), 122883. doi: https://doi.org/10.1016/j.jclepro.2020.122883.

He, L., \& Chen, L. (2020). The incentive effects of different government subsidy policies on green buildings. Renewable and Sustainable Energy Reviews, 135 (2021), 110123, doi: https://doi.org/10.1016/j.rser.2020.110123

Hu, M., Suhendri, Zhao, B., Ao, X., Cao, J., Wang, Q., Riffat, S., Su, Y., \& Pei, G. (2020). Effect of the spectrally selective features of the cover and emitter combination on radiative cooling performance. Energy and Built Environment. doi: https://doi.org/10.1016/j.enbenv.2020.06.008

Kong, X., Qiao, X., \& Yuan, G., (2020). Investigation of thermal environment and the associated energy consumption of transportation buildings along the expressways in the cold region of China: A case study. Energy and Built Environment, (1), 278-287. doi: https://doi.org/10.1016/j.enbenv.2020.03.004

Li, B., You, L., Zheng, M., Wang, Y., \& Wang, Z. (2020). Energy consumption pattern and indoor thermal environment of residential building in rural China. Energy and Built Environment, (1), 327-336. doi: https://doi.org/ 10.1016/j.enbenv.2020.04.004

Murga, A., Long, Z., Yoo, S.-J., Sumiyoshi, E., \& Ito, K. (2020). Decreasing inhaled contaminant dose of a factory worker through a hybrid Emergency Ventilation System: Performance evaluation in worst-case scenario. Energy and Built Environment, (1), 319-326. doi: https://doi.org/10.1016/j.enbenv.2020.04.007

Norouzi, N., \& Kalantari, G. (2020). The sun food-water-energy nexus governance model a case study for Iran. WaterEnergy Nexus, (3), 72-80. doi: https://doi.org/ 10.1016/j.wen.2020.05.005 
Norouzi, N., Fani, M., \& Nasiri, Z. (2021). The development of a Nexus based green architecture ranking system in Iran. Civil Engineering Beyond Limits (CEBEL), 2(2).

Norouzi, N., \& Soori, M. (2020). Energy, environment, water, and land-use nexus based evaluation of the global green building standards. Water-Energy Nexus, (3), 209-224.

Porumb, V.-A., Maier, G., \& Anghel, I. (2020). The impact of building location on green certification price premiums: Evidence from three European countries, Journal of Cleaner Production, (2720), 122080. doi: https://doi.org/ 10.1016/j.jclepro.2020.122080

Reed, R., Bilos, A., Wilkinson, S., \& Schulte, K. W. (2009). International comparison of sustainable rating tools. JOSRE J. 1, 1-22.

Sussman, E. (2008). Reshaping Municipal and County Laws to Foster Green Building, Energy Efficiency and Renewable Energy. $16 N Y$ U. ENVTL. LJ $1,8$.

Wang, L., \& Zheng, D. (2020). Integrated analysis of energy, indoor environment, and occupant satisfaction in green buildings using real-time monitoring data and on-site investigation. Building and Environment, 182, 107014. doi: https://doi.org/10.1016/j.buildenv.2020.107014.

Wu, X., Lin, B., Papachristos, G., Liu, P., \& Zimmermann, N. (2020). A holistic approach to evaluate building performance gap of green office buildings: A case study in China. Building and Environment, (175), 106819. doi: https://doi.org/10.1016/j.buildenv.2020.106819

Yadegaridehkordi, E., Hourmand, M., Nilashi, M., Alsolami, E., Samad, S., Mahmoud, M., Alarood, A. A., Zainol, A., Majeed, H. D., \& Shuib, L. (2020). Assessment of Sustainability Indicators for Green Building Manufacturing Using Fuzzy Multi-Criteria Decision Making Approach. Journal of Cleaner Production, 122905. doi: https://doi.org/10.1016/j.jclepro.2020.122905.

Zhilei, L., Chow, D. H. C., De, D., Jia, Y., Yingjian, H., Hong, C., \& Wei, Z. (2020). The Development and Realisation of a Multi-Faceted System for Green Building Planning: A Case in Ningbo Using the Fuzzy Analytical Hierarchy Process. Energy and Buildings, 110371. doi: https://doi.org/10.1016/j.enbuild.2020.110371 